\title{
NEW SORBUS SUBG. TORMARIA (S. LATIFOLIA AGG.) SPECIES FROM THE SOUTHWESTERN PART OF THE TRANSDANUBIAN MOUNTAIN RANGE (KESZTHELY MTS, HUNGARY)
}

\author{
Csaba NÉmETH ${ }^{1}$, Elemér BARABITS ${ }^{2}$ and Jana BíLÁ ${ }^{3}$ \\ ${ }^{1}$ Department of Botany and Soroksár Botanical Garden, Faculty of Horticultural Science, \\ Szent István University, H-1118 Budapest, Villányi út 29-43, Hungary; nemetcsaba@gmail.com \\ ${ }^{2}$ Alsótekeres Nursery, H-8130 Enying, Fenyö u. 4, Hungary \\ ${ }^{3}$ Department of Botany, Faculty of Science, Charles University, \\ CZ-128 01 Prague, Benatska 2, Czech Republic
}

Németh, Cs., Barabits, E. \& Bílá, J. (2016): New Sorbus subg. Tormaria (S. latifolia agg.) species from the southwestern part of the Transdanubian Mountain Range (Keszthely Mts, Hungary). Studia bot. hung 47: 297-318.

Abstract: Three new triploid Sorbus species, S. concavifolia, S. rhombiformis, and S. vallusensis are described in Sorbus nothosubgenus Tormaria (Sorbus latifolia group) from the Keszthely Mts (Hungary). Illustrations (photographs of the type specimens, leaves, and fruits) and detailed distribution maps are provided, as well as photographs of in situ flowering and fruiting individuals.

Key words: endemic, Hungary, hybridisation, Sorbus latifolia agg., speciation, Tormaria

\section{INTRODUCTION}

Regarding genus Sorbus, the Keszthely Mts seem to be the least investigated region in the Transdanubian Mountain Range in Hungary. This fact has been reflected in the low number of herbarium specimens deposited in Herbarium Carpato-Pannonicum of the Hungarian Natural History Museum (BP). The majority of these materials was collected in the southern hills of the mountains, mainly above the village Balatongyörök (KÁRPÁTI 1960). Apart from some sporadic gatherings, the remaining parts of the range have been underrepresented by Sorbus herbarium materials, respectively.

As a common endemism of the Keszthely Mts and the neighbouring Bakony Mts, the foremost Tormaria Májovský et Bernátová species Sorbus bakonyensis (Jáv.) Kárp. was described by Sándor Jávorka (JÁvoRKA 1927). Two decades later, S. balatonica Kárp. was published (KÁRPÁTI 1949) and in the next year additional taxa (S. andreanszkyana Kárp., S. decipientiformis Kárp., S. gayeriana Kárp., S. latissima Kárp.) were circumscribed (KÁRPÁTI 1950) (Fig. 1). Subsequently Kárpáti 
in his monographic work summarised the knowledge of his age about Sorbus taxa of Hungary and the ambient regions, including species growing in the Keszthely Mts (KÁRPÁti 1960). After a long pause Sorbus research revived only in the 2000s. NÉMETH (2014) reported a systematic Sorbus mapping in the mountains and provided several new localities of most of the formerly described species as well as pointed out the existence of some undescribed taxa growing above Vállus.

Recently, referring to certain previous typification processes SOMLYAY and SENNIKOV (2014) introduced a new name, S. udvardyana for the traditionally well defined species $S$. bakonyensis causing with this a reasonable entanglement in the nomenclature of the so called S. bakonyensis-group as a whole.

\section{MATERIAL AND METHODS}

Systematic field surveys were conducted in the mountains between 2002 and 2016. Geographic coordinates and altitudes were determined using Garmin eTrex Legend GPS. In the course of the typification process (NÉmETH 2010) all the herbarium materials stored in the Hungarian Natural History Museum (BP) and labelled as coming from the Keszthely Mts were revised. The nomenclature of vascular plants follows KIRÁLY (2009).
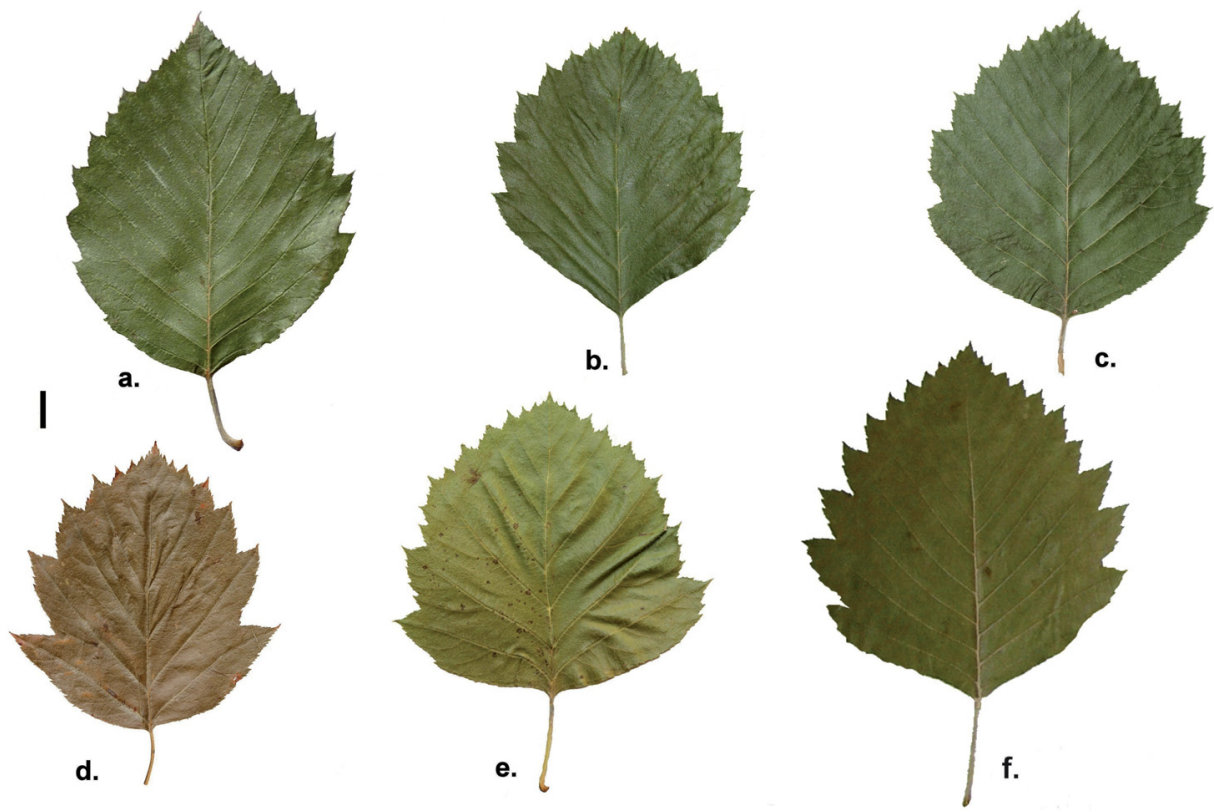

Fig. 1. Typical leaves of formerly described Tormaria taxa occurring in the Keszthely Mts: (a) $=S$. andreanszkyana, $(\mathrm{b})=S$. bakonyensis, $(\mathrm{c})=S$. balatonica,$(\mathrm{d})=S$. decipientiformis, $(\mathrm{e})=S$. gayeria$n a,(\mathrm{f})=S$. latissima $($ scale bar: $1 \mathrm{~cm})$. 
To determine somatic ploidy level of the species fresh leaf samples were collected and analysed by flow cytometer.

\section{RESULTS}

Previous field studies of genus Sorbus in the Keszthely Mts were focused on the southern part of the mountains (JávorKA 1927, KÁRPÁTI 1949, 1950, 1960) and whitebeams, growing in the northern regions were neglected. Field work carried out by the present authors in the last decades however, has revealed that these outlying, northern territories show similar richness in Sorbus as experienced in the southern dolomite hills, close to Lake Balaton.

Beyond the long known and well identifiable species, plenty of unclassifiable "morphotypes" belonging to subgenus Tormaria (including hybridogenous taxa between $S$. torminalis (L.) Crantz and $S$. aria agg.) were also observed during the mapping of recent distribution of Sorbus taxa in the Keszthely Mts. Most of them are represented by one or just a few individuals, which are not necessarily worth having a binominal name of their own taking into consideration their uncertain chance to survive and spread enough in the future to become "real, good" species. There are, however, some "morphotypes", which have a well outlined range and considerable population size. They may deserve to be treated at species rank and to have their own binominal names.

\section{Sorbus concavifolia Cs. Németh, sp. nov.}

(Figs 2-7)

Holotype: Hungary, Zala County Keszthely Mts, Vállus, Láz-tető, mészkedvelö tölgyesben [ $=$ in calciphilous oak forest], $46.83760^{\circ} \mathrm{N}, 17.31028^{\circ} \mathrm{E}, 379$ m, 16.07.2011; leg. Cs. Németh, BP 751073 (3700/1-1/2) (Fig. 2).

Isotype: BP $751074(3700 / 1-2 / 2)$.

Paratypes: Vállus: Kis-láz Valley (Cs. Németh \& G. Mészáros, 31.07.2011, HCsN 3767/1). - Láz Hill (Cs. Németh, 16.07.2011, HCsN 3690, HCsN 3691, HCsN 3692, HCsN 3693/1, HCsN 3693/2, HCsN 3696/3, HCsN 3697/1, HCsN 3698/1, HCsN 3699/1, HCsN 3701/1, HCsN 3702/7, HCsN 3711; Cs. Németh \& G. Mészáros, 31.07.2011, HCsN 3749/2, HCsN 3750/5, HCsN 3761/1, HCsN 3763/1, HCsN 3764/1, HCsN 3774/1, HCsN 3775/1, HCsN 3778/1, HCsN 3782/1, HCsN 3782/2, HCsN 3782/3, HCsN 3783/2, HCsN 3783/3, HCs N3786; Cs. Németh \& P. Erzberger, 07.10.2013, HCsN 5080; Cs. Németh, 01.08.2014, HCsN 6055, HCsN 6062; Cs. Németh \& G. Mészáros, 09.05.2015, HCsN 6626, HCsN6627, HCsN 6629, HCsN 6630, HCsN 6637, HCsN 6638; Cs. Németh, 30.09.2016, HCsN 8331). - Méhes Valley (Cs. Németh, 31.07.2011, HCsN 3774, HCsN 3775/1). 
Description: Small tree to 7-8 m. Bark of trunks grey. Buds ovoid, 士acute, olive green with greyish hairs on narrow brown scale margins. Leaves simple, broadly ovate to nearly broadly elliptic, strongly concave, somewhat spoon shaped, widest at the middle part of lamina, upper surface light green, glossy, lower surface greenish-grey, sparsely hairy, for the autumn it can become apparently hairless (Fig. 3), texture fairly thick. Leaf margin minutely serrate. Broad leaves from fertile and sterile shoots similar in shape, $7.5-10 \mathrm{~cm}$ long and 7-9 $\mathrm{cm}$ wide, base broadly acute to rounded (or often cordate on fertile shoots), held at an angle of $120-180^{\circ}$, cordate ones $200^{\circ}$. Number of lateral veins $10-11$ on each lamina side. Length of the distal margin of the longest (usually the second from the base) lobe 7-12 $\mathrm{mm}$. Apex and lateral lobes of the leaves acute or acuminate. Petiole $1.7-2.5(-3) \mathrm{cm}$ (Fig. 3). Sepals triangular, densely tomentose. Petals white, anthers 20, cream-coloured, styles 2, split to base. Mature fruits broadly ovate to broadly elliptical, 16-18 $\mathrm{mm}$ long and 14-16 mm wide, brown at maturity, densely spotted with approximately equal sized lenticels (Figs 4-5). Flowering in May (Fig. 6), fruits maturing in September.

Distinguishing from similar taxa: The strongly concave leaf lamina of $S$. concavifolia is very characteristic and fairly unique among Hungarian Sorbus species. After pressing and drying the leaves they become wrinkled or often torn at their margins (this is particularly true for rigid autumn leaves). This phenomenon can also be seen less pronouncedly in the leaves of S. vallusensis (see below) and rarely occurs in the leaves of $S$. gayeriana. Completely different leaf shape, serration, and fruit morphology, however, distinguishes $S$. concavifolia from $S$. vallusensis. $S$. gayeriana, similarly to $S$. concavifolia also has a broadly rounded or occasionally cordate leaf base. However, leaf margin of S. gayeriana is strongly, roughly serrate as opposed to the fine, tiny serration of $S$. concavifolia leaves. Furthermore, leaves of $S$. gayeriana are usually the widest under the lower part of the lamina rather than in the middle as seen in S. concavifolia (Fig. 1e, Fig. 3).

Geographical distribution, habitat, and population size: Distribution of $S$. concavifolia seems to be restricted to the northern region of the Keszthely Mts and the species has hitherto been found exclusively on the dolomite massif of Láz Hill and its lateral valleys Kis-láz Valley and Méhes Valley above Vállus. Here, nevertheless, a lot of trees juvenile to adult can be found in thermophilous oak forests (Vicio sparsiflorae-Quercetum pubescentis Zólyomi ex Borhidi et Kevey 1996) and their margins at forest tracks. The total number of individuals of the whole population can be estimated to at least 100. All the occurrences fall into grid cell 9169.4. The area of estimated occupancy is $16 \mathrm{~km}^{2}$ (Fig. 7). Other congeners co-occurring occasionally with $S$. concavifolia are $S$. bakonyensis, S. balatonica, S. concavifolia, S. danubialis (Jáv.) Kárp., S. gayeriana, S. rhombiformis, $S$. subdanubialis agg., S. vallusensis. 


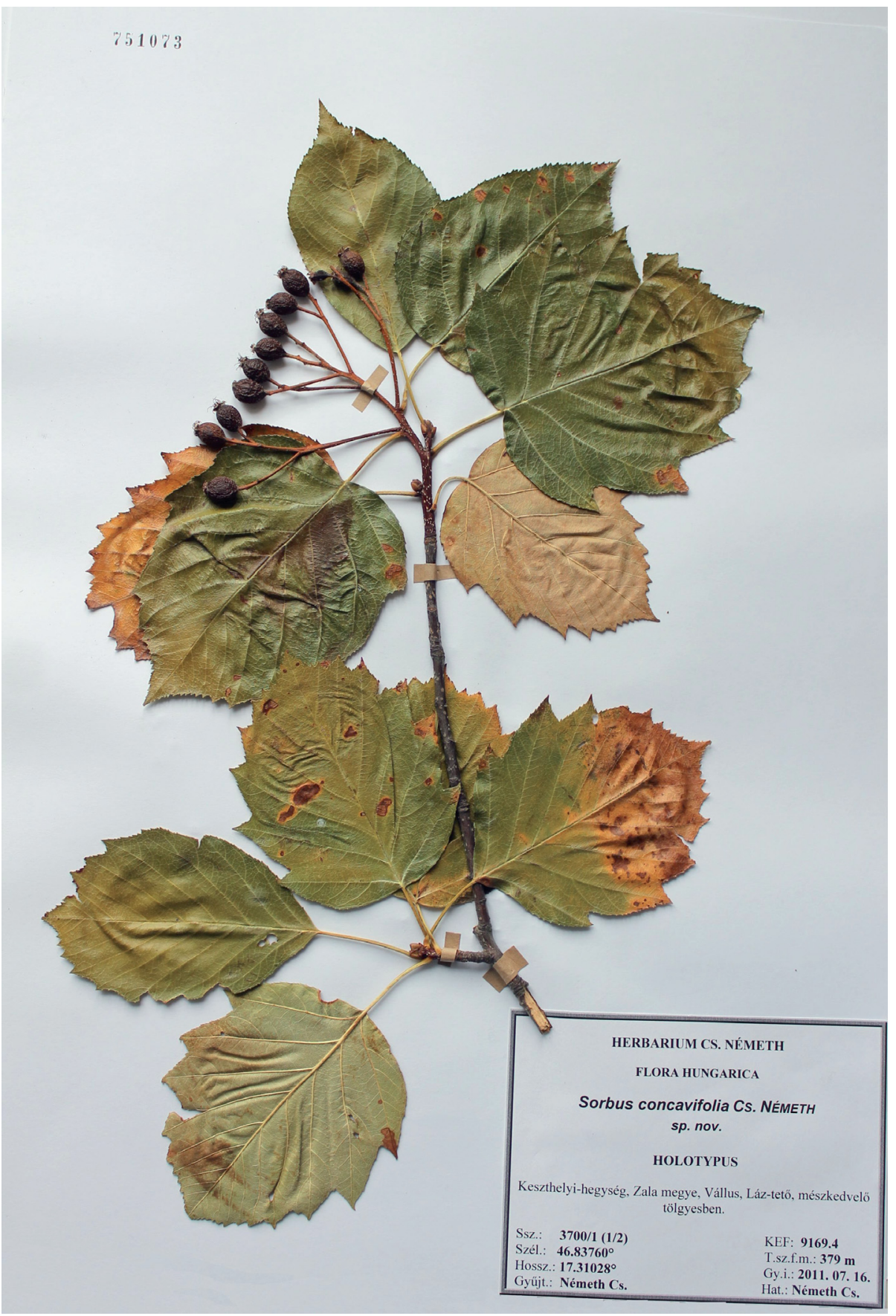

Fig. 2. Holotype of Sorbus concavifolia (scale bar: $10 \mathrm{~cm}$ ). 


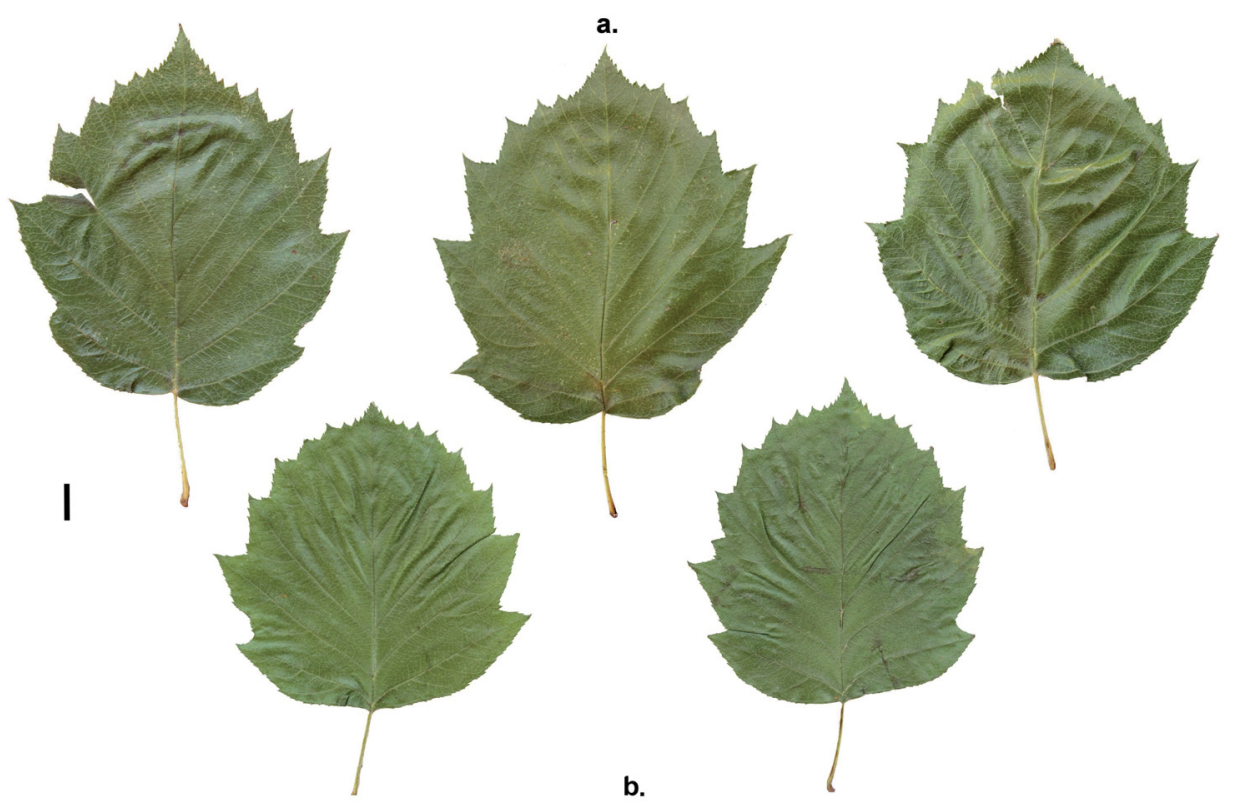

Fig. 3. Typical leaves of Sorbus concavifolia; $(a)=$ from fertile shoots; $(b)=$ from sterile shoots (scale bar: $1 \mathrm{~cm}$ ).

Origin: Morphological features suggest that $S$. concavifolia has arisen from hybridisation of a local polyploid member of $S$. aria agg. and the diploid $S$. torminalis, hence it should be grouped into nothosubg. Tormaria. DNA ploidy level of S. concavifolia is triploid (vouchers of plants examined HCsN 6055, HCsN 6058, HCsN 6062).
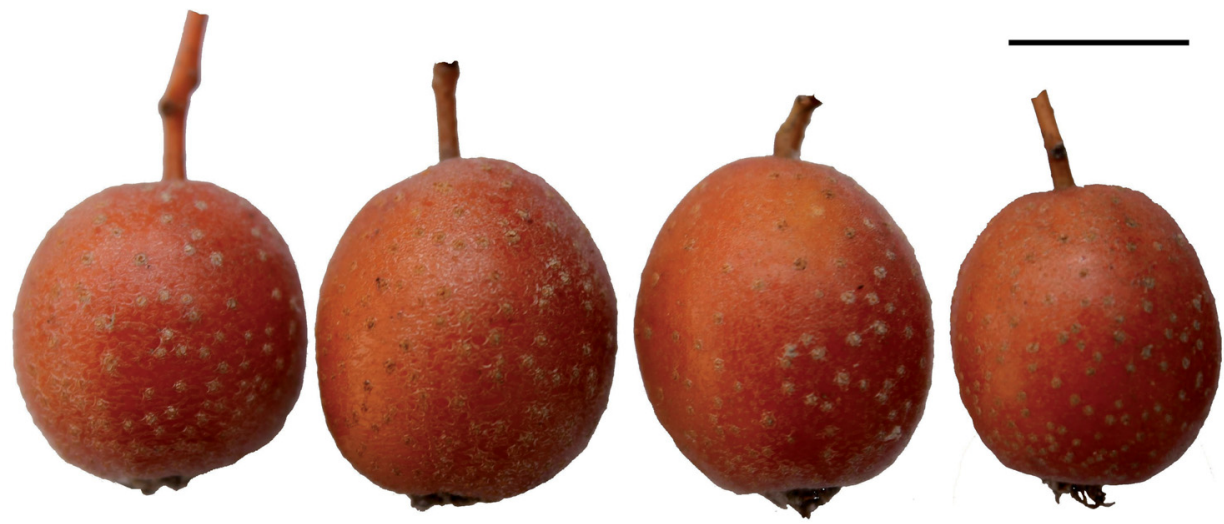

Fig. 4. Mature fruits of Sorbus concavifolia (scale bar: $1 \mathrm{~cm}$ ). 


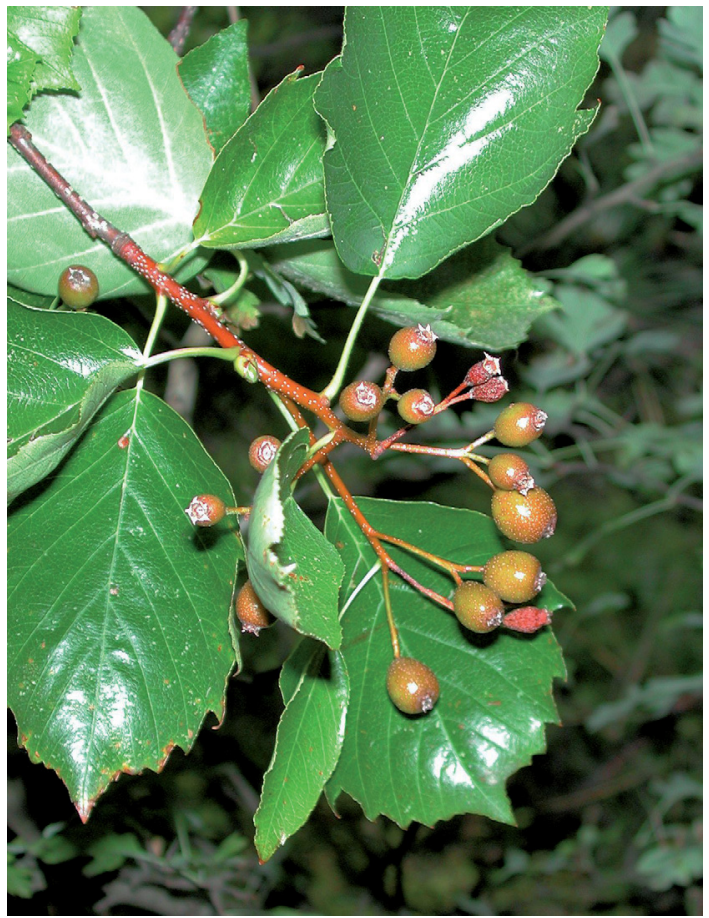

Fig. 5. Fruiting shoot of Sorbus concavifolia (Láz Hill, 06.08.2011, photo by G. Mészáros).

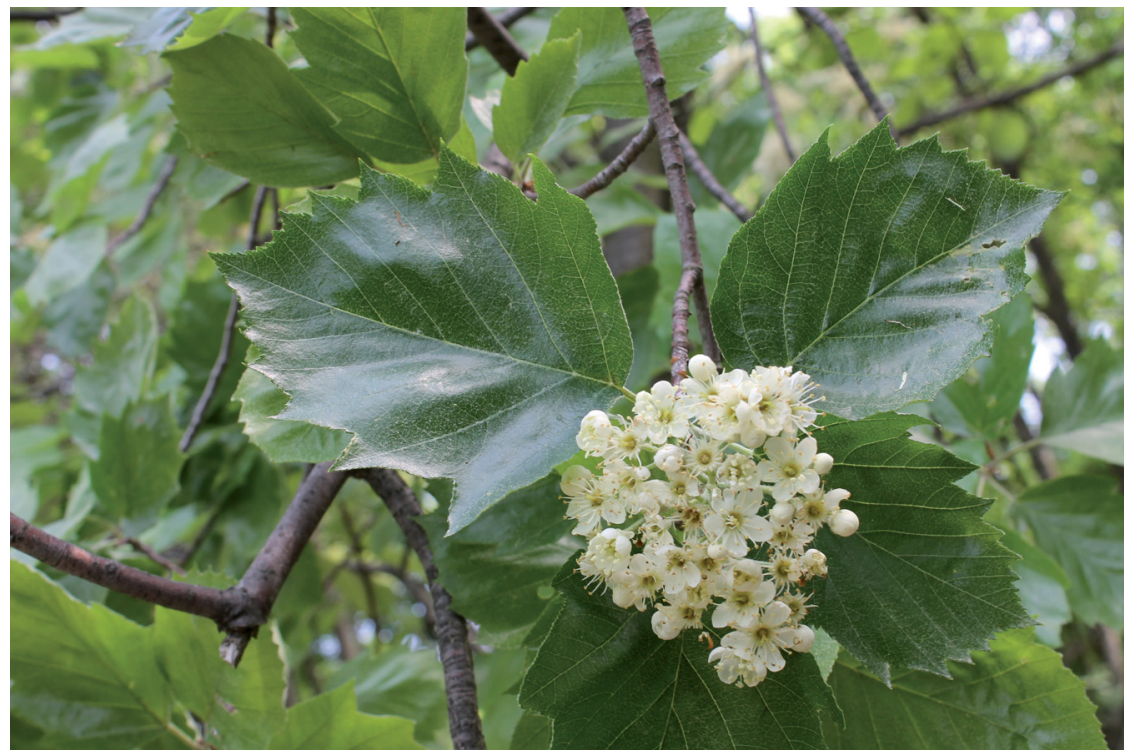

Fig. 6. Flowering shoot of Sorbus concavifolia (Láz Hill, 9 May 2015, photo by Cs. Németh). 


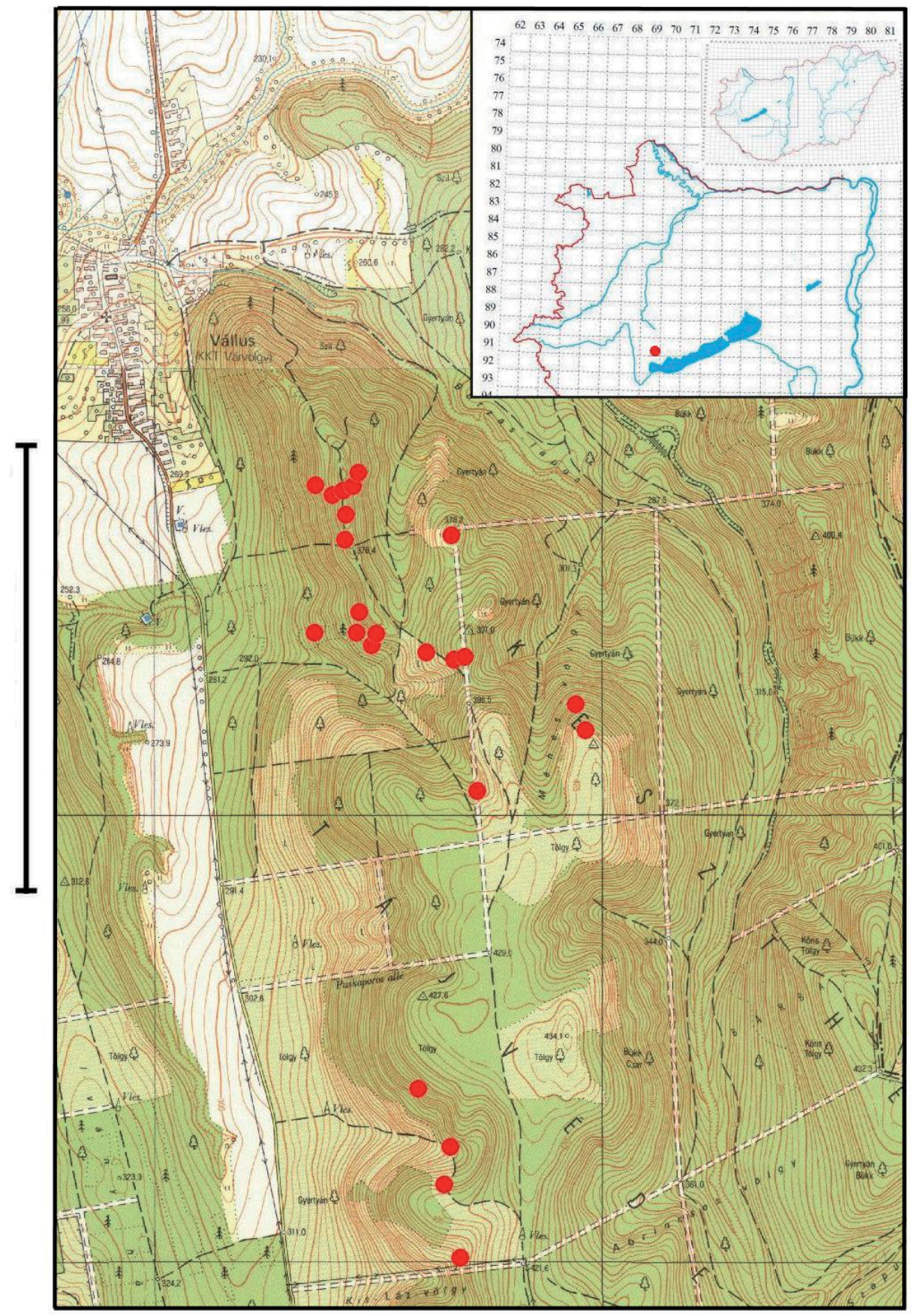

Fig. 7. Distribution of Sorbus concavifolia (scale bar: $4 \mathrm{~km}$ ). 
Etymology: The epithet "concavifolia" refers to the characteristic concaveshaped leaves of the species.

History: According to the present knowledge S. concavifolia was first collected on 31 July 2011 by Cs. Németh.

Sorbus rhombiformis Barabits et Cs. Németh, sp. nov.

(Figs 8-13)

Holotype: Hungary, Zala County Keszthely Mts, Vállus, Láz Hill, above cave Vadlány-lik $46.84434^{\circ} \mathrm{N}, 17.30539^{\circ} \mathrm{E}, 268 \mathrm{~m}, 17.07 .2010$; leg. Cs. Németh, BP 751075 (3325) (Fig. 8).

Isotype: BP 751076.

Paratypes: Vállus: Láz Hill, above cave Vadlány-lik (Cs. Németh, 17.07.2010, HCsN 3326, HCsN 3327/1, HCsN 3328; 16.07.2011, HCsN 3678/4, HCsN 3679/1, HCsN 3679/2, HCsN 3681/4, HCsN 3684/3, HCsN 3687/1, HCsN 3688/1; Cs. Németh \& P. Erzberger 07.10.2013, HCsN 5068, HCsN 5072, HCsN 5085, HCsN 5086; Cs. Németh, 01.08.2014, HCsN 6051, HCsN 6052; Cs. Németh \& G. Mészáros, 09.05.2015, HCsN 6633, HCsN 6652, HCsN 6654; Cs. Németh, 30.09.2016, HCsN 8334). - Méhes Valley (Cs. Németh, 31.07.2011, HCsN 3776/1).

Other collections (planted ornamental trees): Csókakő (Cs. Németh, 27.07.2012, HCs N4547; 06.07.2014, HCs N5741), Komárom (Cs. Németh, 22.09.2015, HCsN 7289), Székesfehérvár (Cs. Németh, 12.05.2012, HCsN 4281), Telki (Cs. Németh \& G. Mészáros, 08.07.2016, HCsN 8059/1).

Description: Small tree to 5-6 m. Bark of trunks grey. Buds ovoid, tacute, bud scales olive green with brownish, pilose margins. Leaves simple, broadly rhombic or ovate-rhombic, usually as long as wide, sometimes slightly wider than long, widest at the middle part of lamina, upper surface green, dull to somewhat glossy, lower surface greenish to greenish-grey, sparsely hairy, for the autumn become hairless (Fig. 9), texture fairly thick. Leaf margin unevenly biserrate. Broad leaves from fertile and sterile shoots very similar in shape, $7-10 \mathrm{~cm}$ long and wide, base broadly cuneate rarely on fertile shoots broadly rounded, held at an angle of $100-130(-140)^{\circ}$. Number of lateral veins 8-9 on each side. Length of the distal margin of the longest (usually the lowest) lobe 10-15(-17) $\mathrm{mm}$. Apex and lateral lobes of the leaves finely acuminate. Petiole conspicuously long, 2-3.5(-4) cm (Fig. 9). Sepals triangular, densely tomentose. Petals white, anthers 20, cream-coloured, styles 2, split to base. Mature fruits ovate, $18-20 \mathrm{~mm}$ long and 14-16 mm wide, brown at maturity, densely spotted with lenticels (Figs 10-11). Flowering in May (Fig. 12), fruits maturing in September. 


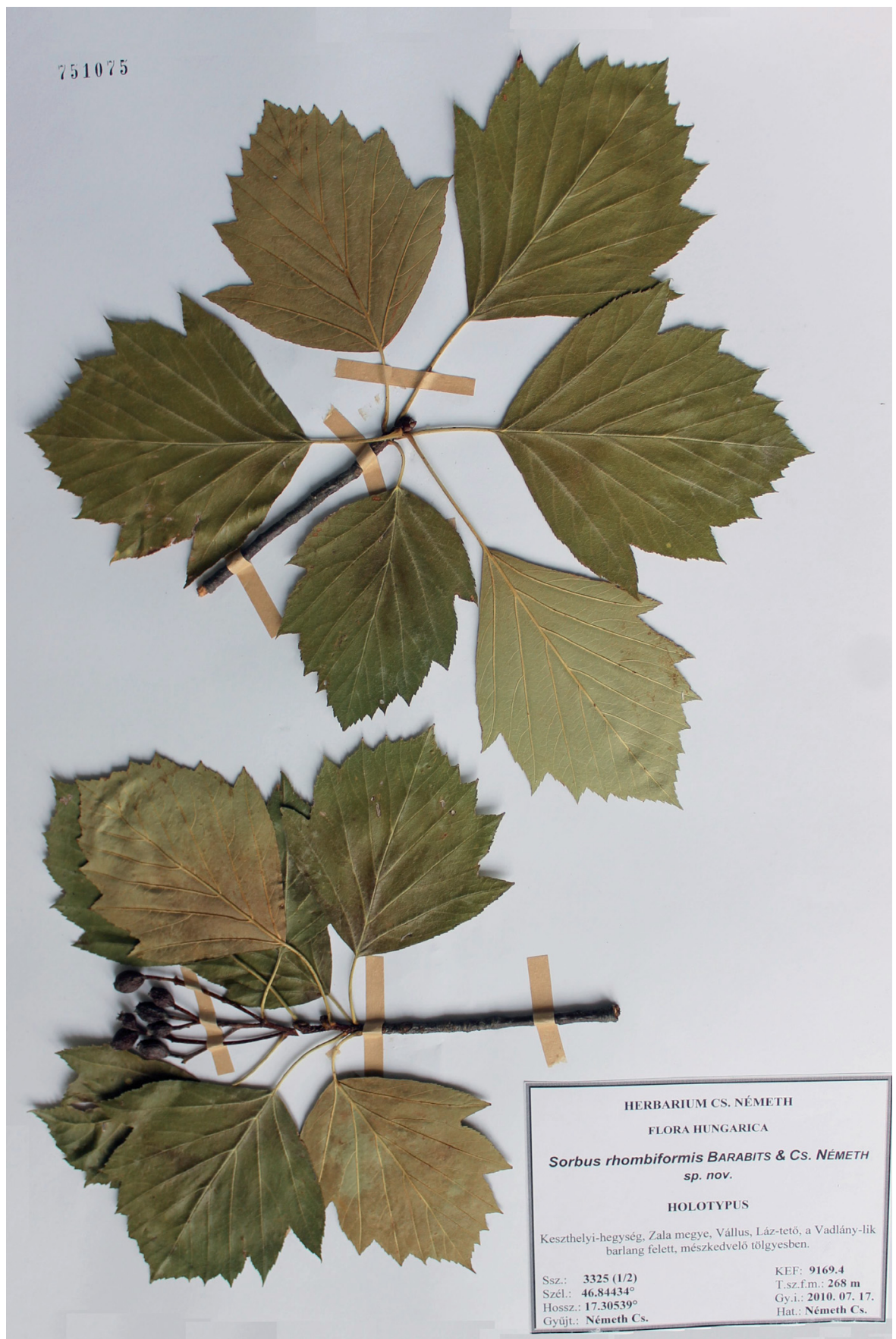

Fig. 8. Holotype of Sorbus rhombiformis (scale bar: $10 \mathrm{~cm}$ ). 


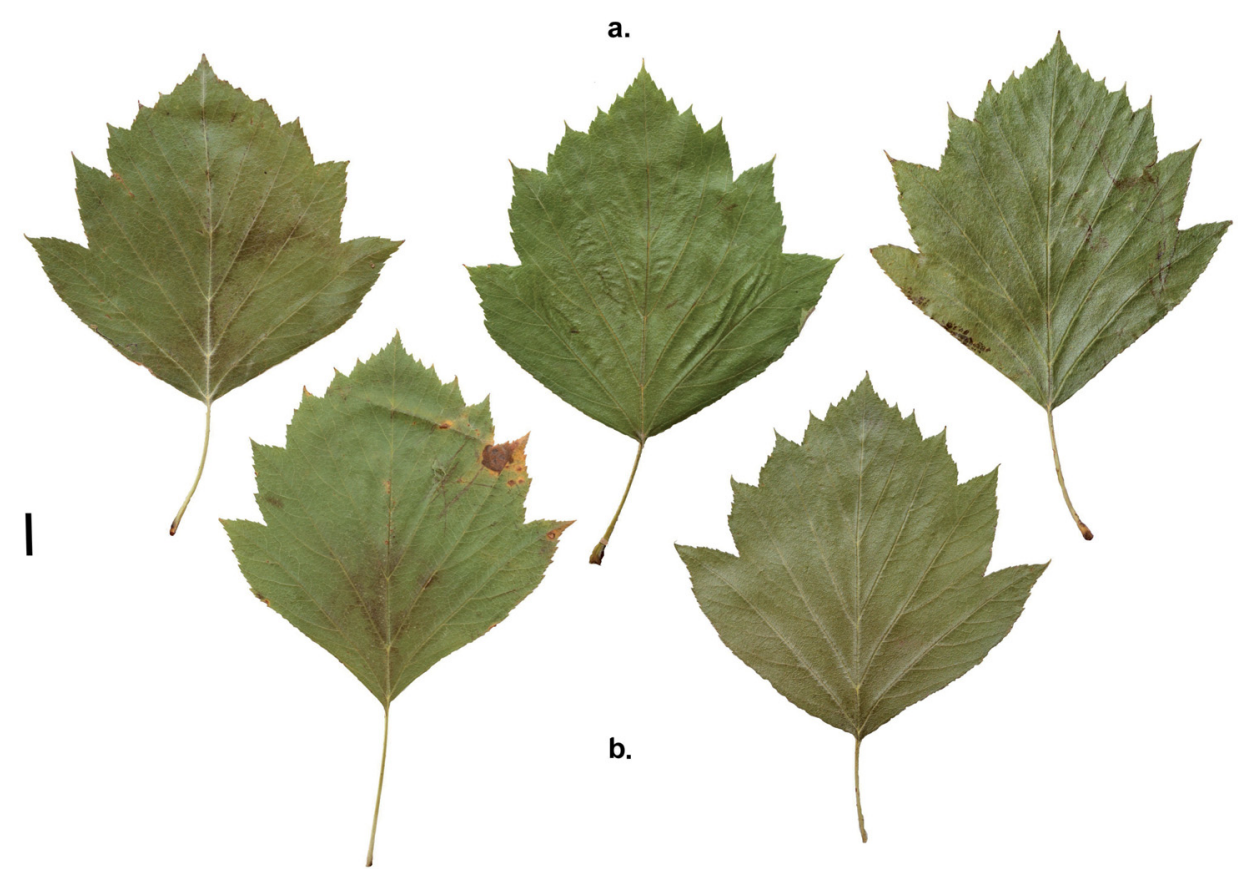

Fig. 9. Typical leaves of Sorbus rhombiformis; $(a)=$ from fertile shoots; $(b)=$ from sterile shoots (scale bar: $1 \mathrm{~cm}$ ).

Distinguishing from similar taxa: S. rhombiformis is similar to S. decipientiformis with which it was previously confused. S. rhombiformis has wide rhombicshaped leaves with cuneate base in contrast with the ovate leaves of $S$. decipientiformis, which usually have rounded, rarely a broadly cuneate base (Fig. 1d, Fig. 9).
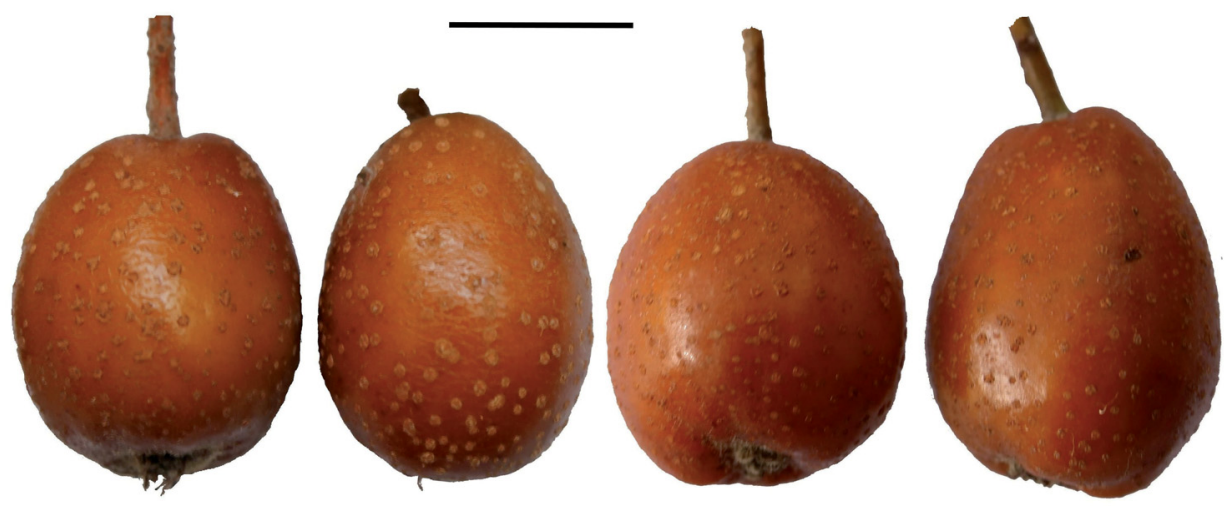

Fig. 10. Mature fruits of Sorbus rhombiformis (scale bar: $1 \mathrm{~cm}$ ). 


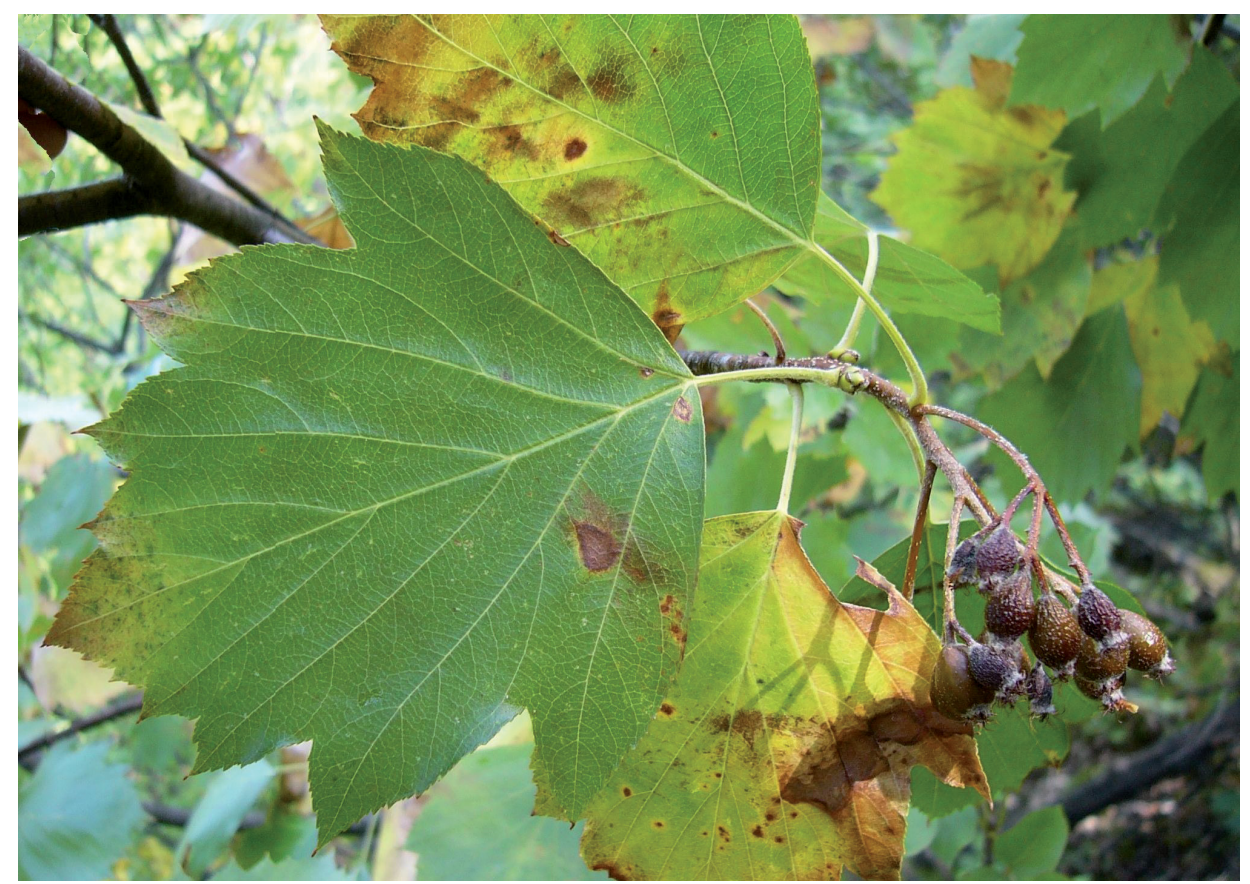

Fig. 11. Fruiting shoot of Sorbus rhombiformis (Láz Hill, 16 July 2011, photo by Cs. Németh).

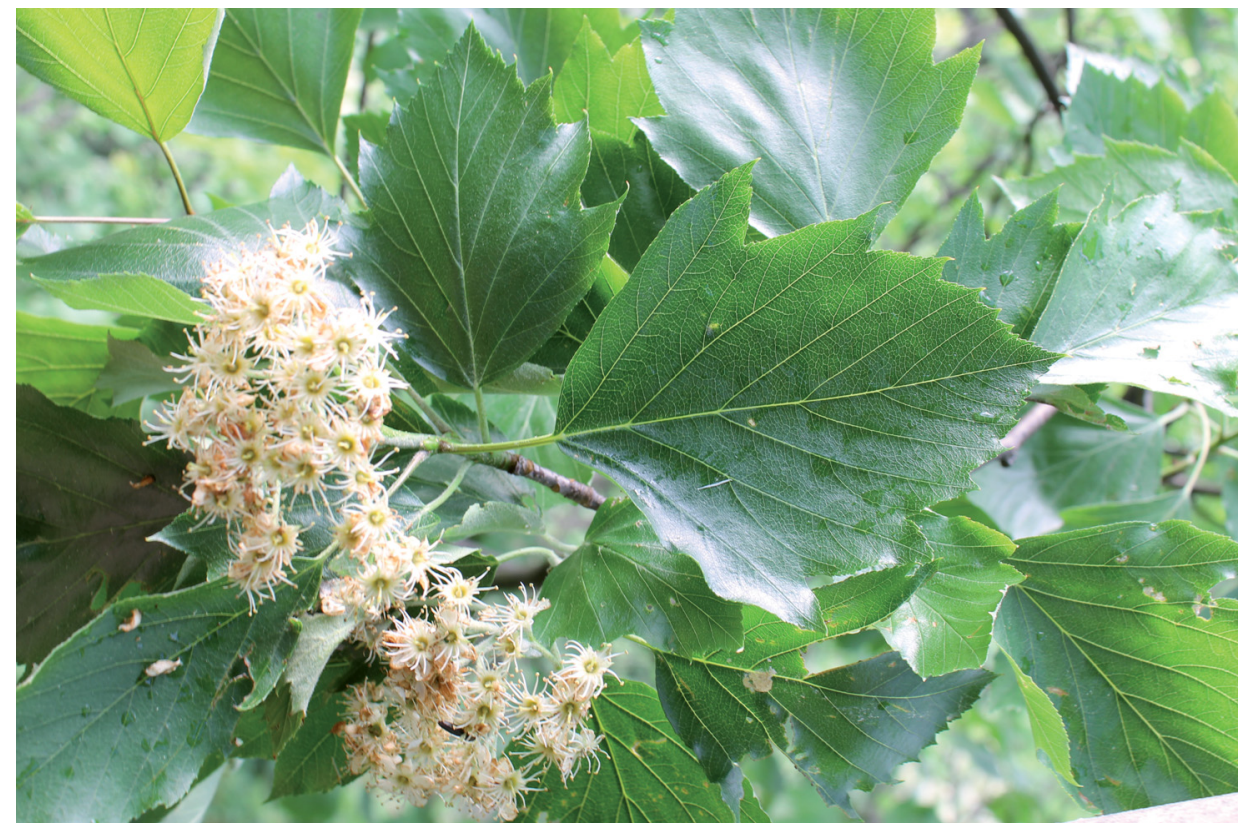

Fig. 12. Flowering shoot of Sorbus rhombiformis (Láz Hill, 9 May 2015, photo by Cs. Németh). 


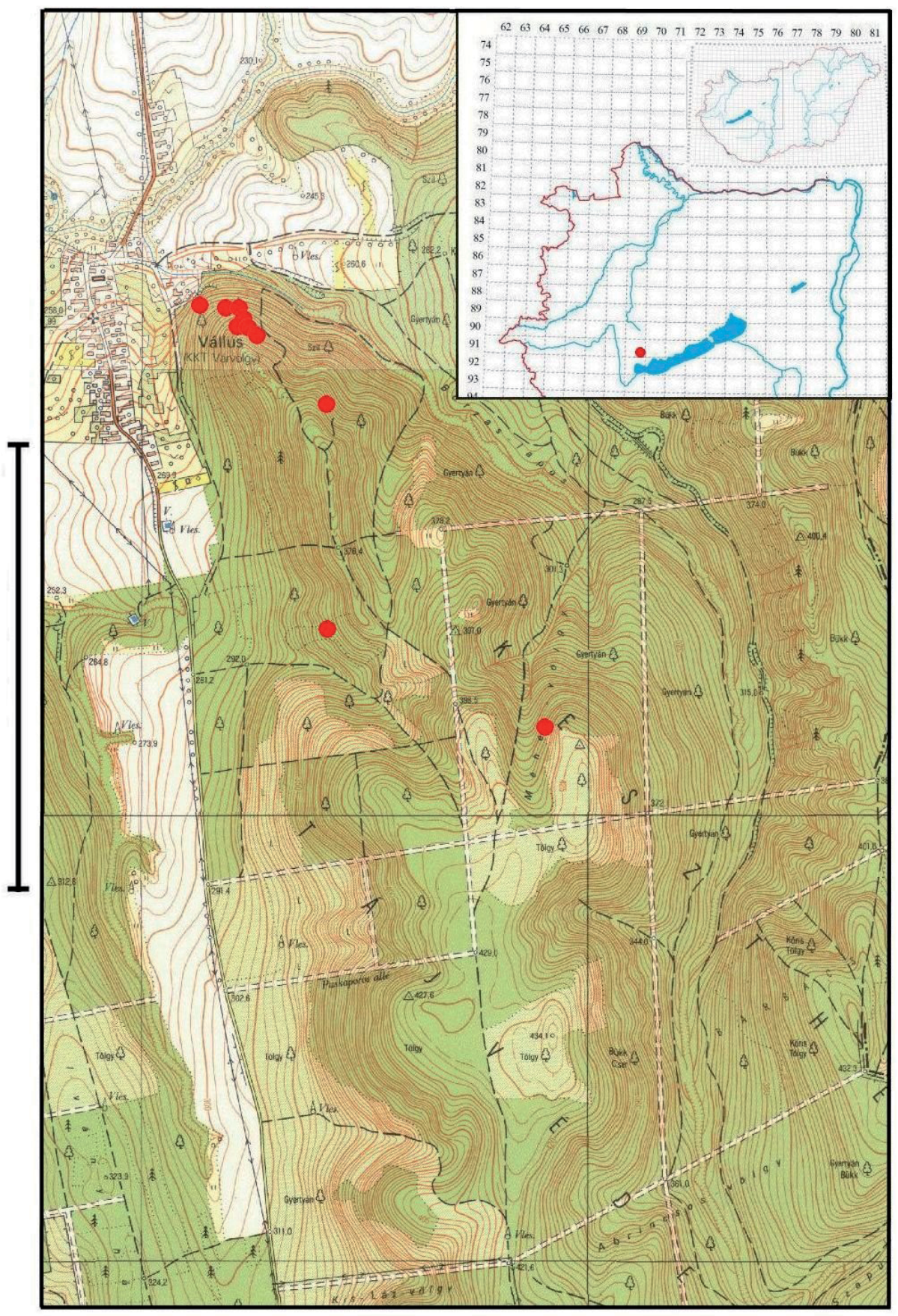

Fig. 13. Distribution of Sorbus rhombiformis (scale bar: $4 \mathrm{~km}$ ). 
Geographical distribution, habitat, and population size: Distribution of $S$. rhombiformis is restricted to the northern slopes of Láz Hill, where about 20 individuals of different age were observed in closed thermophilous oak woodlands (Vicio sparsiflorae-Quercetum pubescentis), mixed karstic forests (Fago-Ornetum Zólyomi (1950) 1958), and mixed forests of rocky slopes (Primulo veris-Tilietum platyphyllae (Isépy 1968) Borhidi 1996) developed on Triassic dolomite bedrock. Some additional single trees were encountered further southeastward too. The total number of individuals can be estimated to 40. All the occurrences fall into grid cell 9169.4. The estimated area of occupancy is $8 \mathrm{~km}^{2}$ (Fig. 13). Congeners growing together with $S$. rhombiformis are $S$. bakonyensis, S. balatonica, S. concavifolia, S. danubialis, S. gayeriana, S. subdanubialis agg., S. vallusensis.

An unusual and interesting situation has emerged from the fact that many more individuals of $S$. rhombiformis exist in cultivation as street ornamental trees than they do in nature (see more in chapter History).

Origin: Based on its leaf and fruit morphology S. rhombiformis should be classified into nothosubg. Tormaria including species having originated by hybridisation of $S$. aria group and $S$. torminalis. S. rhombiformis is triploid (vouchers of plants examined HCsN 5741, HCsN 6051, HCsN 6052).

Etymology: The epithet "rhombiformis" refers to the characteristic rhombicshaped leaves of the species.

History: According to our present knowledge S. rhombiformis was first collected by Elemér Barabits in 1991 above village Vállus in order to cultivate it in his nursery (Alsótekeres, Central Hungary). Subsequently, due to its regular shaped crown and other favourable horticultural features, this species, sold as $S$. decipientiformis "Vállus", has become a widely cultivated ornamental tree in public places of many settlements all over Hungary. S. decipientiformis, otherwise, has not turned up since its discovery and description (KÁRPÁTI 1950, NÉMETH 2010, 2014), although numerous field trips have been made by the first author in its type locality and other sites covering almost the overall mountain. Similar morphotypes represented by a single or a few individuals have been encountered, but they show only superficial resemblance with the type material of $S$. decipientiformis and cannot be identical with that.

Sorbus vallusensis Cs. Németh, sp. nov.

(Figs 14-20)

Holotype: Hungary, Zala County Keszthely Mts, Vállus, Láz-tető, 46.83729 N, 17.31243 E, 379 m, 16.07.2011; leg. Cs. Németh, HCsN 3709/1, BP 751077 (Fig. 14). 
Paratypes: Vállus: Láz-tető (Cs. Németh, 17.07.2010, HCsN 3329, HCsN 3330; 16.07.2011, HCsN 3680/2, HCsN 3682/1, HCsN 3686/1, HCsN 3689/1, HCsN 3699/3, HCsN 3699/4, HCsN 3699/5, HCsN 3702/1, HCsN 3702/2, HCsN 3702/3, HCsN 3702/4, HCsN 3702/5, HCsN 3702/6, HCsN 3703/1, HCsN 3704/1, HCsN 3705/1, HCsN 3707/7; 31.07.2011, HCsN 3747, HCsN 3748, HCsN 3750/1, HCsN 3771; Cs. Németh \& P. Erzberger, 07.10.2013, HCsN 5074, HCsN 5075, HCsN 5077, HCsN 5078, HCsN 5081, HCsN 5082, HCsN 5084; Cs. Németh, 01.08.2014, HCsN 6059, HCsN 6060, HCsN 6061; Cs. Németh \& G. Mészáros, 09.05.2015, HCsN 6640; Cs. Németh, 30.09.2016, HCsN 8332). Méhes Valley (Cs. Németh, 31.07.2011, HCsN 3773). - Szent Miklós Valley (Cs. Németh, 21.08.2011, HCsN 3900, HCsN 3901/3, HCsN 3904/1, HCsN 3909/1, HCsN 3911/1).

Description: Small tree to 7-8 m. Bark of trunks grey. Buds ovoid, 士acute, bud scales olive green with brownish, sparsely tomentose margins. Leaves simple, broadly ovate, somewhat concave, widest slightly below the middle, upper surface green, glossy with a slightly convex surface between veins, lower surface greenish-grey, moderately tomentose, for the autumn becomes sparsely hairy (Fig. 15), texture thick. Leaf margin \pm biserrate. Broad leaves of fertile and sterile shoots similar in shape, $9-12.5 \mathrm{~cm}$ long and $7-11 \mathrm{~cm}$ wide, base broadly rounded to broadly cuneate, held at an angle of $130-160(-170)^{\circ}$. Number of lateral veins 11-12 on each lamina side. Length of the distal margin of the longest lobe 7-12 mm. Apex and lateral lobes of the leaves acuminate. Petiole $2.0-2.5(-3) \mathrm{cm}$ (Fig. 15). Sepals triangular, densely tomentose. Petals white, anthers 20, creamcoloured, styles 2, split to base. Mature fruits ovate, 15-17 mm long and 12-14 mm wide, brown at maturity, densely spotted with numerous small and few large, whitish lenticels (Figs 16-17). Flowering in May (Fig. 18), fruits maturing in September.

Distinguishing from similar taxa: S. vallusensis shares some resemblance with S. semiincisa Borb. and S. pseudolatifolia Boros, two species endemic to the northeastern region of the Transdanubian Mountain Range and Vértes Mts, respectively. Both of them have completely different fruits being globose or subglobose in shape (not ovate) and dotted more densely by lenticells. In addition, mature fruits of $S$. semiincisa are red rather than brown in colour as those of $S$. vallusensis. Based on leaf features the three species are also easily distinguishable from one another. Leaf lobes of both $S$. pseudolatifolia and S. semiincisa are more pronouncedly acuminate and more acutely serrate. Furthermore, the lower surface is more densely tomentose with more greenish tinge in S. pseudolatifolia and with more whitish one in S. semiincisa. S. vallusensis is close to S. latissima in leaf characters, but the latter differs from the former in having rougher leaf serration, acute and not acuminate leaf lobes, greater number of lateral veins (12-13) 


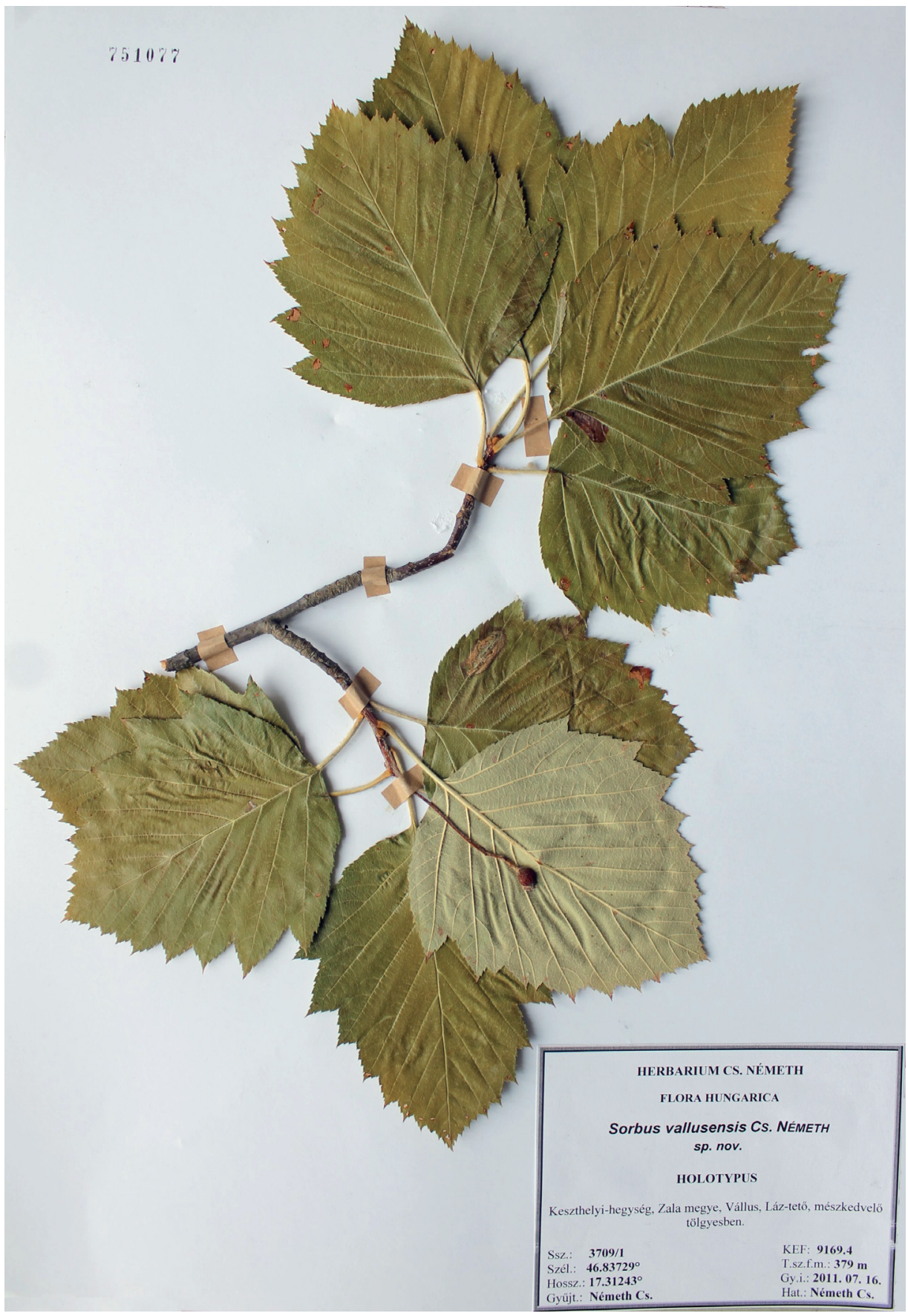

Fig. 14. Holotype of Sorbus vallusensis (scale bar: $10 \mathrm{~cm}$ ). 


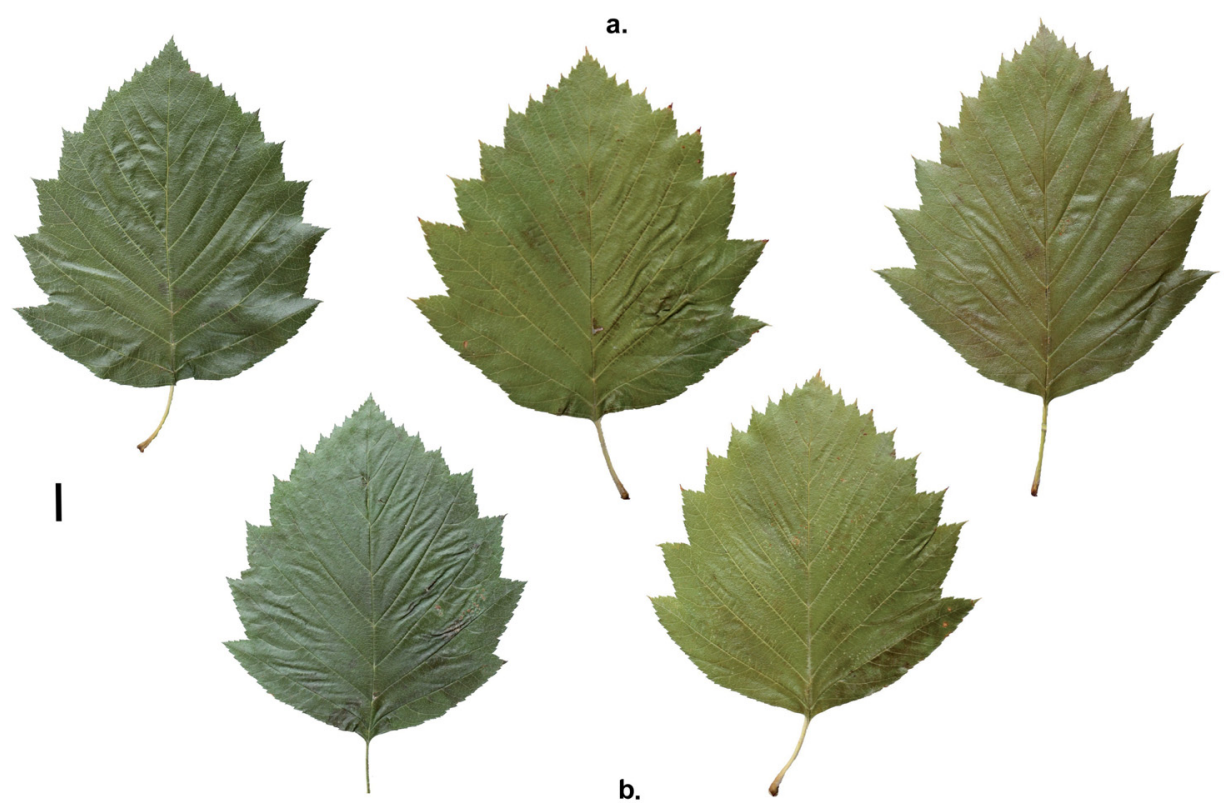

Fig. 15. Typical leaves of Sorbus vallusensis; $(a)=$ from fertile shoots; $(b)=$ from sterile shoots (scale bar: $1 \mathrm{~cm}$ ).

and more narrowly cuneate leaf base. In having moderately convex surface between lateral veins of the leaves $S$. vallusensis resembles $S$. pelsoensis Cs. Németh, a stenoendemism of Balaton Uplands, but differs from that in possessing totally dissimilar leaf shape and lobe characters as well as red, globose fruits rather than brownish ovate ones (Fig. 19).
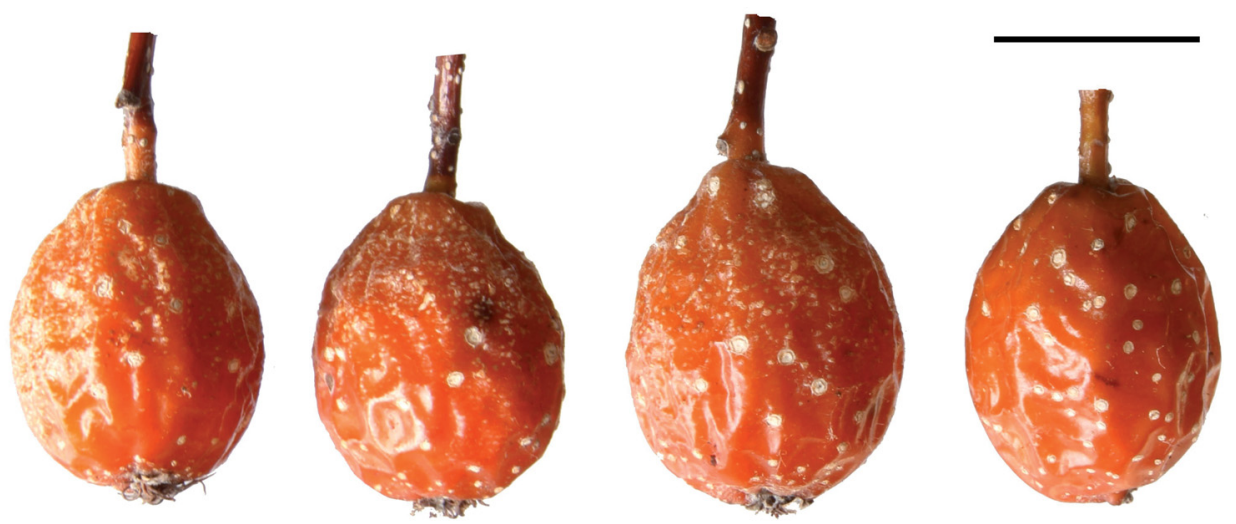

Fig. 16. Mature fruits of Sorbus vallusensis (scale bar: $1 \mathrm{~cm}$ ). 


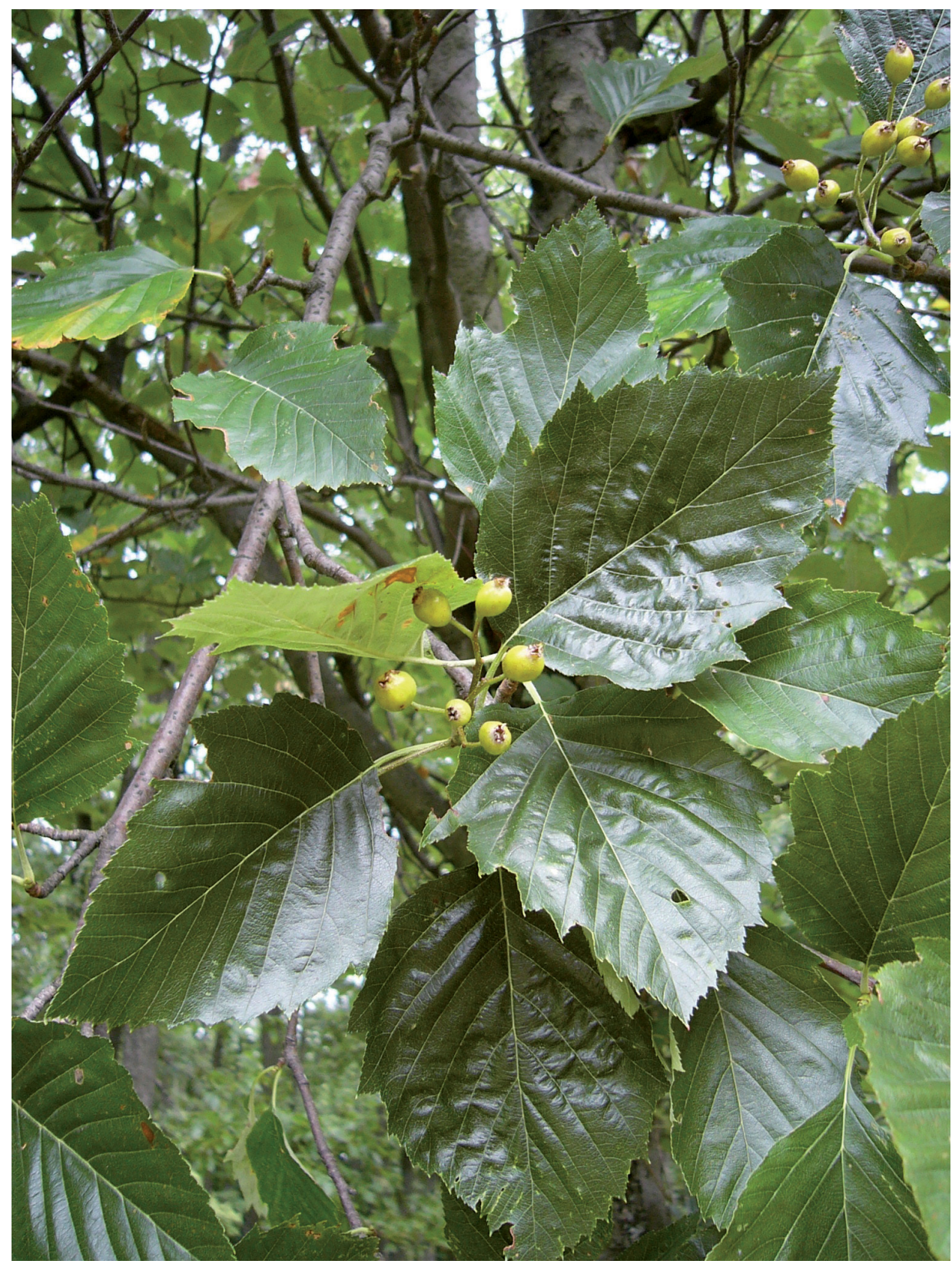

Fig. 17. Fruiting shoot of Sorbus vallusensis with immature fruits (Láz Hill, 31.07.2011, photo by Cs. Németh). 


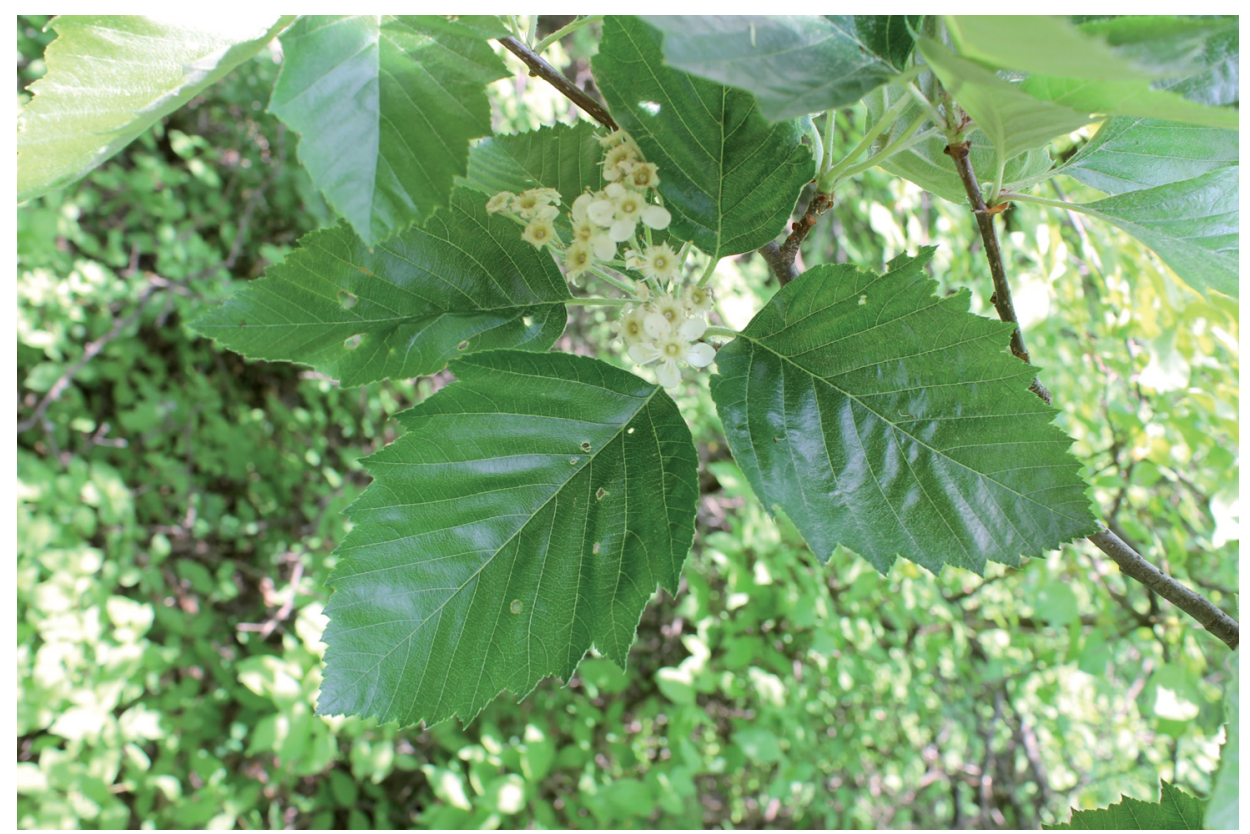

Fig. 18. Flowering shoot of Sorbus vallusensis (Láz Hill, 9 May 2015, photo by Cs. Németh).
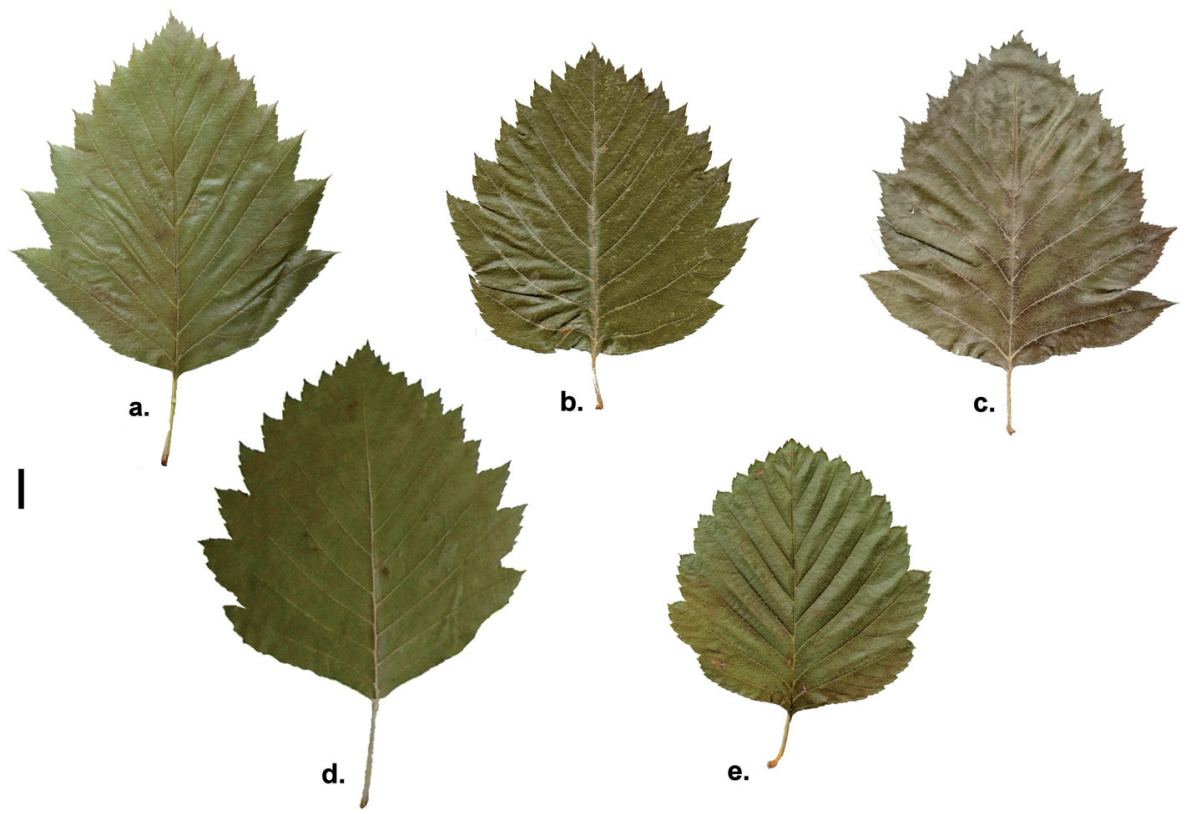

Fig. 19. Typical leaves of Sorbus vallusensis and the most similar species: $(\mathrm{a})=$ S. vallusensis, (b) $=S$. semiincisa, $(\mathrm{c})=S$. pseudolatifolia, $(\mathrm{d})=S$. latissima,$(\mathrm{e})=S$. pelsoensis (scale bar: $1 \mathrm{~cm})$. 


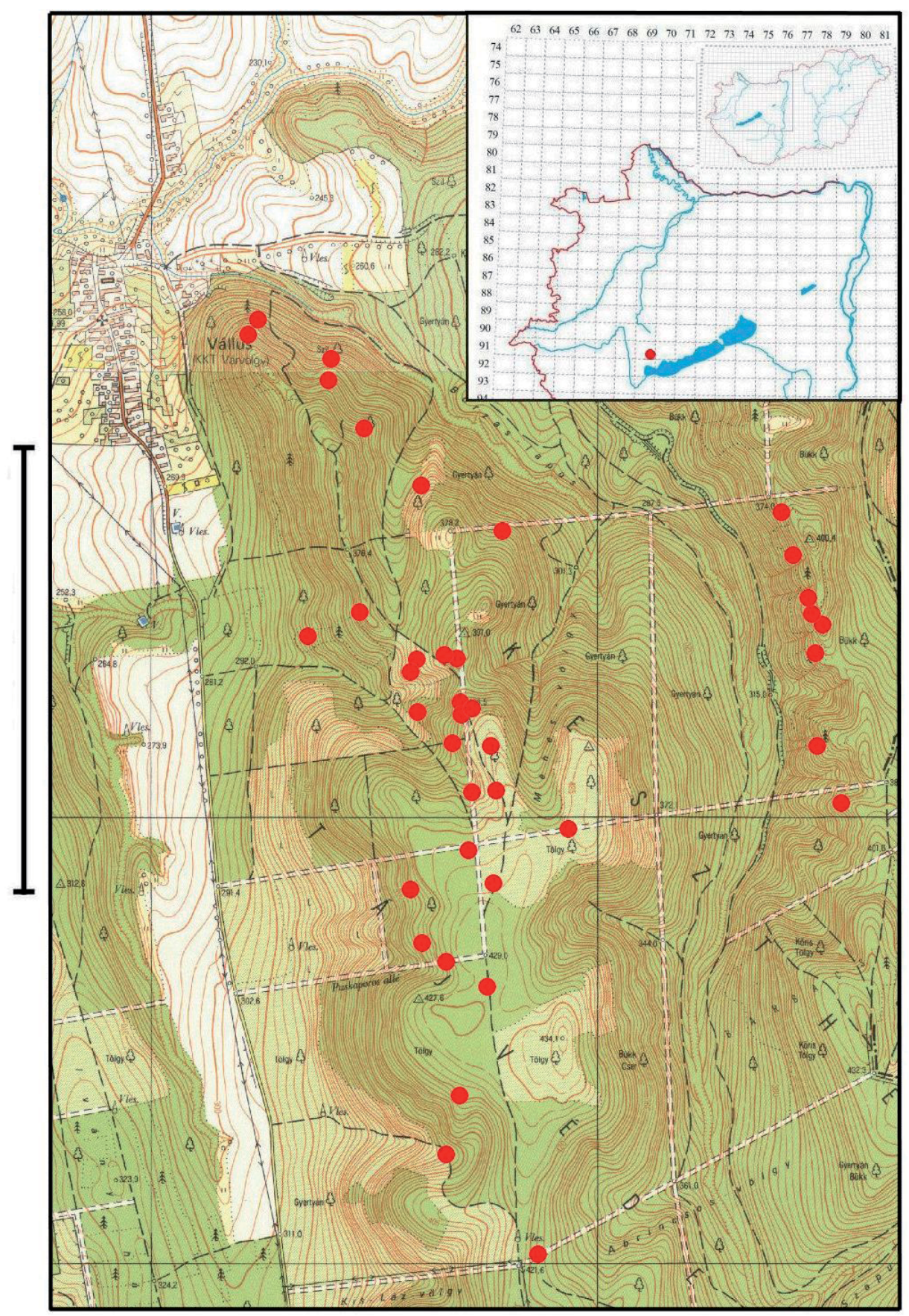

Fig. 20. Distribution of Sorbus vallusensis (scale bar: $4 \mathrm{~km}$ ). 
Geographical distribution, habitat, and population size: Of the species described here $S$. vallusensis has the widest distribution range and the largest number of individuals. Aside from the plateau and side valleys of Láz Hill it occurs on the western steep slopes of the neighbouring Szent Miklós Valley. It tends to grow sympatrically with the following congeners: S. bakonyensis, S. balatonica, S. concavifolia, S. danubialis, S. gayeriana, S. rhombiformis, S. subdanubialis agg. Individuals of $S$. vallusensis with various age are present in closed thermophilous oak woodlands (Vicio sparsiflorae-Quercetum pubescentis) and mixed forests of rocky slopes (Primulo veris-Tilietum) often mixed with planted pine trees. The total number of individuals can be estimated to at least 150. All the occurrences fall into grid cell 9169.4. The estimated area of occupancy is $25 \mathrm{~km}^{2}$ (Fig. 20).

Origin: Sorbus vallusensis unambiguously belongs to nothosubg. Tormaria and has been derived from hybridisation of $S$. aria agg. and $S$. torminalis. It represents a triploid cytotype (vouchers of plants examined HCsN 6059, HCsN 6060, HCsN 6061).

Etymology: Epithet "vallusensis" refers to the name of the small village Vállus situated close to the habitats of $S$. vallusensis.

History: S. vallusensis was first collected by Cs. Németh on 17 July 2010.

\section{DISCUSSION}

Keszthely Mts has been the least surveyed part of the Transdanubian Mountain Range from the point of view of Sorbus, although they do not fall behind the other regions in variety and variability of whitebeams at all. Two main hybridisation centres appear to have been evolved in the mountains. One of them, Bodorhálás Hill and its surroundings above Balatongyörök has been known for a long time and served formerly as the primary source for describing new Sorbus species. The other hybridisation hot spot with extraordinary variety of Sorbus has been discovered just recently in the northern corner of the territory. Láz Hill and the adjacent area, similarly to Bodorhálás and its adjoining hills can be regarded as a microevolutionary hot spot where exceedingly intensive hybridisation processes can be studied.

With the three new Sorbus species, S. concavifolia, S. rhombiformis, and $S$. vallusensis published here the total number of Tormaria species occurring in the Keszthely Mts has increased to nine. Three of the previously described six taxa, the most widespread ones, S. bakonyensis, S. balatonica, and S. gayeriana are common endemisms with the close Bakony Mts and Balaton Uplands, respectively. Occurrences of $S$. andreanszkyana are confined to the Bodorhálás Hill and the ambient hills in the southeastern region. The remaining two, S. decipientiformis and S. latissima, are quite mysterious taxa without any known recent occurrences. They are exclusively represented by a couple of herbarium sheets (including the 
type materials) collected from the same locality, at the same time, presumably from the same (possibly single) trees. Such single or few tree morphotypes have currently also been found in the mountain in great abundance.

Acknowledgements - We thank P. Erzberger and G. Mészáros for support in the field. Special thanks to G. Mészáros for providing photograph of fruiting $\mathrm{S}$. concavifolia.

Összefoglaló: A Keszthelyi-hegység Sorbusokban való gazdagsága régóta ismert. A nemzetséggel elmélyültebben foglalkozó kutatók (Jávorka Sándor, Boros Ádám, Kárpáti Zoltán) mind megfordultak a területen, terepbejárásaik azonban inkább a hegység déli területeire fókuszálódtak, míg az északi dolomitrögök napjainkig szinte teljesen feltáratlanok maradtak. Az elmúlt két évtized terepi megfigyelései a Baltongyörök feletti, már korábbról ismert hibridizációs centrum mellett az északi területek hasonlóan egyedülálló fajgazdagságára is rávilágítottak. Ennek eredményeként a hegységből korábban leírt és jelzett $S$. andreanszkyana, S. bakonyensis, S. balatonica, $S$. decipientiformis, $S$. gayeriana és $S$. latissima fajok mellett további, eddig nem ismert Tormaria fajok is elökerültek. A jelen cikkben leírásra kerülő S. concavifolia, S. rhombiformis és $S$. vallusensis fajok közös jellemzője, hogy mindegyikük hibrid eredetü, a barkócaberkenye ( $S$. torminalis), valamint a lisztes berkenye alakkör ( $S$. aria agg.) egyik tagjának kereszteződésével jött létre, mindhárom taxon triploid és földrajzi elterjedésük a Keszthelyi-hegység északi, Vállus környéki területeire korlátozódik.

\section{REFERENCES}

JÁvorka S. (1927): A Sorbus torminalis (L.) Cr. magyar keverékfajai. - Magyar Bot. Lapok 25: 83-90.

KÁRPÁTI, Z. (1949): Taxonomische Studien über die zwischen Sorbus aria und Sorbus torminalis stehenden Arten und Bastarde im Karpathenbecken. - Hung. Acta Biol. 1(3): 94-125.

KÁRPÁTI, Z. (1950): Újabb taxonómiai vizsgálatok a Sorbus aria s.l. és a S. torminalis közé eső hazai berkenyéken. [Newer taxonomic research of the Hungarian sorb trees between Sorbus aria s.l. and S. torminalis]. - Agrártud. Egyet. Kert. Szölögazd. Tud. Kar Évk. 1: 31-52.

KÁrpáti, Z. (1960): Die Sorbus-Arten Ungarns und der angrenzenden Gebiete. - Feddes Repert. 62: 71-331.

KIrÁLy, G. (ed.) (2009): Új magyar füvészkönyv. Magyarország hajtásos növényei. Határozókulcsok. (New Hungarian herbal. The vascular plants of Hungary. Identification key). - Aggteleki Nemzeti Park Igazgatóság, Jósvafö, 616 pp.

Németh, Cs. (2010): Taxonomic revision, typification and validation of Sorbus (Rosaceae) taxa in the Herbarium Carpato-Pannonicum in Budapest I. - Acta Bot. Hung. 52(3-4): 377-397. http://dx.doi.org/10.1556/ABot.52.2010.3-4.14

NÉmeth, Cs. (2014): Sorbus-kutatások a Keszthelyi-hegység területén. - Aktuális Flóra- és Vegetációkutatás a Kárpát-medencében X., Sopron, pp. 64-65.

Somlyay, L. and Sennikov, A. (2014): Atlas Florae Europaeae notes 23. The typification and revised taxonomic circumscription of Sorbus bakonyensis (Rosaceae), with a description of Sorbus udvardyana, a new apomictic species endemic to Hungary. - Phytotaxa 164(4): 265-275. http://dx.doi.org/10.11646/phytotaxa.164.4.5

(submitted: 30.09.2016, accepted: 10.11.2016) 